Article

\title{
Sustainable Supply Chain Management, Digital-Based Supply Chain Integration, and Firm Performance: A Cross-Country Empirical Comparison between South Korea and Vietnam
}

\author{
Su-Yol Lee
}

check for updates

Citation: Lee, S.-Y. Sustainable Supply Chain Management, Digital-Based Supply Chain

Integration, and Firm Performance: A Cross-Country Empirical Comparison between South Korea and Vietnam. Sustainability 2021, 13, 7315. https:// doi.org/10.3390/su13137315

Academic Editors: Joon Koh and Sang Cheol Park

Received: 30 May 2021

Accepted: 28 June 2021

Published: 30 June 2021

Publisher's Note: MDPI stays neutral with regard to jurisdictional claims in published maps and institutional affiliations.

Copyright: (C) 2021 by the author. Licensee MDPI, Basel, Switzerland. This article is an open access article distributed under the terms and conditions of the Creative Commons Attribution (CC BY) license (https:// creativecommons.org/licenses/by/ $4.0 /)$.
College of Business Administration, Chonnam National University, Yongbong-ro 77, Buk-gu, Gwangju 61186, Korea; leesuyol@jnu.ac.kr; Tel.: +82-62-530-1446

\begin{abstract}
Sustainability and digitization issues have coevolved in supply chain management (SCM), receiving attention from the academic and business circles. However, few studies have addressed this topic in an integrated way. In this regard, this study examined the relationships between sustainable SCM, digital-based supply chain integration, and supplying firms' performance in two different country settings: South Korea and Vietnam. This comparative study provides evidence that sustainable SCM facilitates the adoption and implementation of supply chain integration using digital technologies, leading to suppliers' operational competitiveness. This study also indicates the differences and similarities of sustainable SCM and its effects in the two different economies. These findings provide scholars, managers, and policymakers with theoretical and practical implications to encourage firms in Asian countries to enhance corporate competitiveness by adequately responding to environmental and social issues and digitalization along the global value chain.
\end{abstract}

Keywords: sustainable supply chain management; digital-based supply chain integration; operational performance; comparative analysis; structural equation modeling

\section{Introduction}

The last couple of decades have witnessed increasing globalization, rapid technological development, and evolving competitive business environment, which hamper firms' ability to anticipate and manage changes in their global supply chains. Ratcheting uncertainty in the global value chain may jeopardize a firm's financial viability by causing disruptions of its key supply sources [1]. Supply chain risks may originate from several sources, such as commodity price volatility [2], natural disasters [3], and sustainability scandals [4]. For instance, the average annual commodity price volatility in the 2000s has been about three times higher than the 1990s [2]. The 2012 Fukushima tsunami and its consequent nuclear incident caused Toyota's production to drop 40,000 vehicles per day [3]. The Foxconn affair, whose Chinese factory workers repeatedly committed suicide in 2010, led Apple to substitute its largest supplier [5]. Supply chain risks regarding volatility, sustainability, disruptive technologies, and disasters usually have links, increasing the severity of each risk [6]. Supplier and customer integration in the supply chain has received increasing attention as it is believed to enhance supply chain agility to adapt and respond to marketplace changes in a swift manner [1]. In this changing competitive context, this study aims to explore the links between sustainability, supply chain integration, digitization, and operational performance. This study highlights the research purpose and contributions by addressing research streams and gaps in the relevant literature.

The first research stream encompasses sustainability issues in supply chains. Firms have increasingly concerned about their supply chains regarding environmental and social challenges, such as climate change and fair trade. A large number of firms, particularly those utilizing global value chains, have moved forward to build an environmental and responsible supply chain [7]. Sustainable supply chain management (hereafter "sustainable 
$\left.\mathrm{SCM}^{\prime \prime}\right)$ practices have enabled sustainability practices to diffuse in the emerging and developing Asian economies [8,9]. For the past decade, some Asian countries have become one of the world's factories that enable firms to produce high volumes of products at a low cost. Regulatory pressure on corporate sustainability practices in emerging economies tends to be less stringent than in Western and developed countries [8]. Large global companies have pushed their suppliers to adopt environmental-friendly and socially responsible management practices at well-compliant levels with international standards. This movement results in positive sustainability benefits, including worker human rights and safety, community well-being, and nature conservation $[10,11]$.

The second research stream covers the intersection of digital technologies and supply chain management. A demand for digitization of the global value chain has rapidly grown [12]. With the rise of Industry 4.0, digital transformation using various types of advanced technologies, such as cloud computing, big data, and blockchain, helps to simplify the complex structure and accelerate supply chain integration [13]. Firms have attempted to increase collaboration with their various partners, including suppliers and customers, by integrating their materials and information and synchronizing their inter-organizational processes, which is believed to enhance supply chain operations' efficiency [14]. Both researchers and practitioners expect that digitization of supply chains has the potential to significantly achieve enhanced visibility and better collaboration along a supply chain; however, very few companies have successfully implemented digitalbased supply chain integration [12]. For instance, only about five percent among firms recognizing the value of digital transformation of supply chains are satisfied with their approaches towards supply chain digitization [15].

A number of studies have explored sustainability, digitization, and integration in supply chains; however, several essential aspects have received relatively little attention. First, previous studies have examined those research topics in a separate way. For instance, the supply chain management literature has hardly addressed the intersection of digital technologies and sustainability issues in supply chains. Second, understanding of supply chain digitization is in its early stages [13]. Third, the literature of sustainable SCM has characterized its practices [7] and examined the drivers and effects of sustainable SCM $[10,16]$ However, the relationship between sustainable SCM and corporate competitiveness remains inconclusive [8,17]. In this regard, the integration of sustainable SCM into supply chain digitization has become a prominent trend nowadays [18]. Motivated by these gaps in the literature, this study aims to examine the relationships between sustainable SCM, supply chain digitization, and supplying firm performance in two different country settings. This article contributes to the existing literature in three distinct ways.

First, conventional approaches to supply chain integration are facing the challenges of updating to digitization. Previous studies, however, have little discussed the antecedents and consequences of supply chain digitization [19]. There is a deficit in the literature that provides frameworks for both scholars and practitioners to rethink supply chain integration in the digital era. We explore the intersection of sustainable SCM and supply chain digitization. This study is one of the earliest studies that report how sustainability along a supply chain facilitates inter-organizational integration in a global value chain, which leads to competitiveness. Second, the literature of sustainable SCM has focused on large buying firms from a Western country context $[7,16]$. A few studies have examined small and medium-sized supply firms (SME suppliers) in the Asian context $[10,11,20]$. Besides, sustainability practices may differ depending on countries' policies and culture [21]. Comparative studies that explore the differences of sustainable SCM in at least two different institutional contexts are strongly encouraged. This study evaluates how sustainable SCM practices differ in different countries' contexts from a SME supplier perspective. Besides, we present evidence that sustainable SCM enhances the supplier's competitiveness. Third, the existing literature has provided mixed results of the relationship between sustainable SCM and corporate competitiveness [17]. That suggests that sustainable SCM research should consider intervening variables and different contexts to better understand how the 
direction of this relationship differs. By combining digital-based supply chain integration and different country settings, this study presents evidence sustainable SCM influences supplying firms' competitiveness through supply chain digitization; yet, the effects are somewhat different in the two different contexts.

The rest of this study is organized as follows: Section 2 covers the theoretical background of sustainable SCM and digital-based supply chain integration and presents a research model and hypotheses. Section 3 explains the research method. Section 4 discusses the results of the empirical analysis, and the last section concludes with academic and managerial implications and some suggestions for future research.

\section{Theoretical Background and Hypothesis Development}

\subsection{Sustainable Supply Chain Management}

Sustainable SCM is the firm's strategic effort to achieve social, environmental, and economic goals through the systematic coordination of buyer-supplier relationships and inter-organizational business processes [22]. The economic aspect of the triple bottom line has been assumed as being covered by conventional management publications [17]. Thus the literature of sustainable SCM has focused on two dimensions of sustainability: environmental and social aspects [7]. In the literature, the relationship between sustainable SCM and firm performance indicates the link between the triple bottom line's social and environmental performance and economic performance. In general, sustainable SCM activities encompass monitoring and support $[23,24]$. The buying firms conduct monitoring-based sustainable SCM practices toward their suppliers to reduce environmental and social risks in their supply chain. Monitoring integrates sustainability performance criteria into supplier selection processes. Support-based sustainable SCM practices focus more on improving the supply chain's social and environmental performance and emphasize technical assistance, training and education, and information and knowledge sharing $[7,20,25]$. Collectively, sustainable SCM consists of two dimensions: the environmental and social aspects.

First, this study defines the environmental dimension of sustainable SCM as a set of managerial practices to integrate environmental issues into SCM to enhance environmental performance along a supply chain. Global leading companies want to mitigate environment-related risks in their supply chain. Thus, they began to integrate the environmental criteria into performance objectives for supply chain management [26]. Firms have increasingly relied on their supply chain partners to achieve environmental performance [25]. Adopting green procurement policies is a typical practice of the green dimension of sustainable SCM. Buying firms evaluate suppliers' environmental performance through formal supplier assessment criteria. Environmental support includes several activities focusing on suppliers' long-term environmental management capability [24]. Large buying firms provide their suppliers with relevant information and skills to develop environmentally-friendly products/processes through direct and frequent interaction between the buyer and supplier. They also support the suppliers with technical, managerial, and financial assistance to improve suppliers' environmental performance [24].

Second, this study operationalizes the social dimension of sustainable SCM as a set of firms' efforts to reduce social risks such as human rights and improve corporate reputation in the local communities [23]. The United Nations' Global Compact principles, such as human rights, anti-corruption, and diversity, are the most widely used guidelines in addressing social issues in supply chains. Some companies demand their suppliers to acquire social responsibility certificates, such as SA8000. How social criteria are satisfied is left to the suppliers. A strict penalty mechanism such as "three strikes and you are out" may be adopted (e.g., Walmart's sustainable network program [27]). Also, global buying firms provide their suppliers with support programs to improve their social performance. They provide their suppliers with technical and financial support to help them fulfill the code of conduct. 


\subsection{Digital-Based Supply Chain Integration}

Many firms have increasingly paid attention to supply chain integration, which aims to improve efficiency along a supply chain by integrating materials, information, and capital flows and synchronizing supply chain partners' processes [14,28]. In a global value chain, geographical distance has been perceived as a significant challenge for supply chain integration. However, digital transformation has diffused throughout industries, enabling firms to achieve enhanced visibility and better collaboration along a supply chain. Several information and communication technologies, such as electronic data interchange (EDI), enterprise resource planning (ERP), radio frequency and identification (RFID), and computerized shipping and tracking systems, have already been adopted in supply chain management [28]. Based on these existing technologies, firms increasingly incorporate emerging technologies, including cloud computing, big data analytics, the Internet of things, and social media, into their global supply chain management.

By combining supply chain integration and digitization, digital-based supply chain integration can be defined as a set of activities concerned with coordinating product and information flow along a supply chain utilizing digital technologies [28,29]. The digital supply chain integration concept is still developing [30]. From a social capital perspective, it can encompass relational integration and structural integration [31]. The former dimension refers to behavioral and operational integration, includes joint activity development, collaborative work processes, and coordinated decision-making between supply chain partners based on shared goals, trust, and reciprocity. The latter dimension points to the coordination of information transfer and communication among partners based on enablers of digital technologies, including traditional EDI and emerging artificial intelligence (AI), big data analytics, cyber-physical systems, and the Internet of things [19,32]. Digital-based supply chain integration enhances visibility in the supply chain and lowers uncertainty arising from changes in orders and demand volatility. For instance, emerging digital technologies can visualize real-time information sharing among global supply chain partners.

\subsection{Hypotheses Development}

The present study has three main research objectives. First, we investigate the differences and similarities of sustainable SCM in the Korean and Vietnamese contexts. Second, this study tests the effect of sustainable SCM on suppliers' operational performance through digital-based supply chain integration. Third, this study examines how the relationships between sustainable SCM, digital supply chain integration, and performance vary across countries.

Stakeholders' concerns regarding social and environmental issues may significantly affect firms' stance towards sustainability issues. However, stakeholders' pressures are exerted differently in diverse country settings [21,33]. Stakeholders' expectation about sustainability is likely to be higher in Western than Asian countries. However, the gaps in such pressures on firms in developed and developing countries are narrowing. That is because ratcheting demands for better sustainability performance usually initiated by customers in developed countries is passed to local firms located in developing countries through the global supply chain [34].

Large, high-profile firms tend to face considerable pressure to improve their sustainability performance; in contrast, smaller suppliers or suppliers, particularly in developing countries, have few incentives. Sustainability pressures are often transferred upstream to suppliers, stimulating sustainability changes along the supply chain in Asia. Buying firms might require a more stringent sustainability performance of their suppliers to reduce the business risks in emerging markets. Buyers are likely to place more significant pressure on Vietnamese supply firms than Korean ones. Korean firms have been exposed to international markets longer than Vietnamese firms. Many Korean firms have already implemented ISO standards (e.g., ISO14001) and are therefore less likely to be asked about 
sustainability practices from their global buyers. Based on this argument, we present the following hypothesis.

Hypothesis 1 (H1). Sustainable supply chain management practices (i.e., the levels of sustainability requirements and support from the global buying firm) in Vietnam are higher than those in Korea.

Digital-based supply chain integration can significantly achieve enhanced visibility and better collaboration in global supply chains. However, many companies find it challenging to implement digital supply chain integration mainly because of a sense of urgency, lack of strategic orientation, inflexible business processes, misaligned business objectives, and fear of losing confidential information [12]. Sustainable SCM can play a crucial role in overcoming these barriers to digital supply chain integration for some reasons.

First, sustainable SCM is essentially a reciprocal program requiring mutual recognition by supply chain partners [35]. Supply chain partners can share common sustainability goals through a transparent evaluation of environmental and social performance, an effective feedback system, open communication, and sustainability information sharing [36]. Relational social capital, such as trust and mutual understanding, accumulated via sustainable SCM practices can mitigate concerns about confidential information sharing and facilitate the adoption of emerging digital technology for supply chain integration.

Second, sustainable SCM focuses on investment for technical, product development, and management capabilities with a long-term perspective [35]. As buying firms, particularly large global brand companies, perceive their suppliers as partners rather than contractors, they increasingly provide suppliers with technical, financial, and managerial assistance and increase joint activities [36]. Similarly, suppliers perceive buyers' direct involvement in environmental and social performance as a signal of long-term commitment, which leads to lower barriers for digital-based supply chain adoption.

Third, digital transformation increasingly helps organizations achieve better customer service and better relations with suppliers, increasing competitive positions [19,37]. Digital technologies' rapid penetration throughout the entire industry has significantly changed customers' buying behavior and demand patterns. In response to these emerging challenges in supply chain management, digitization enables firms to enhance visibility and better collaboration along a supply chain [37]. A combination of traditional technologies such as EDI, ERP, and RFID with emerging technologies including big data analytics, AI, and real-time data exchange can be a source of supply chain competitive advantage [19,36]. More specifically, information and operational integration among buyers and suppliers using digital technologies lowers uncertainty arising from changes in orders, demand volatility, and lead-time fluctuations. Previous studies have provided evidence that digital technology use facilitates supply chain integration [12,36,38] and improves supply chain performance directly and indirectly $[29,39]$.

Collectively, sustainable SCM enhances strong interaction ties among partners in the global value chain, facilitating buyers and suppliers to adopt and utilize digital technologies for their supply chain integration. Digital-based supply chain integration enables supply chain partners to generate new ideas, find new solutions, work together to solve complex problems, leading to operational performance. This reasoning present the following hypothesis.

Hypothesis 2 (H2). Sustainable SCM is positively related to suppliers' operational performance through digital-based supply chain integration.

This study conjectures that the relationships among sustainable SCM, digital-based supply chain integration, and operational performance can differ in the two different settings of Korea and Vietnam. The levels of maturity in the industrial sector of Korea and Vietnam are different. Such difference may engender some sustainability practices to be implemented at different levels, which varies the effects of sustainable SCM. Besides, the 
contextual differences may matter. For example, social issues, including firms' contribution to local communities and the alleviation of polarization, have recently gained higher priority than environmental problems in Korea. At the same time, the Vietnamese government places importance on reducing air pollution, wastewater, and environmental degradation. Vietnamese firms are at an early stage of sustainability practices to have more options for environmental performance improvements. However, Korean industries' energy efficiency has generally reached the top levels of performance [40]. Thus, increases in energy and environmental performance are very challenging and costly. Due to such differences, the effects of sustainable SCM on competitiveness may vary in the two countries' settings.

Hypothesis 3 (H3). The extent and strength of particular relationships between sustainable SCM, digital-based supply chain integration, and operational performance vary across countries.

\section{Research Methodology}

\subsection{Variables and Measure}

This study employed a survey method. We used previously validated scales whenever possible to increase the reliability and validity of the measurement. Based on the literature, we devised a questionnaire. All the questions were perceptual measures using a sevenpoint Likert-type scale. First, we developed five items to measure the environmental dimension of sustainable SCM based on the previous research on green SCM [24,41]. They included environmental performance criteria in the supplier selection process, auditing, environmental knowledge provision, and technical assistance. An analogous five-item scale was used to measure the social dimension of sustainable SCM adopted from the responsible SCM literature [23,42]. Second, digital-based supply chain integration was measured using five items as an extension of previous studies [28-30]. They encompass information sharing (i.e., order, inventory, and production planning) and coordinated planning decisions (i.e., stock replenishment and joint product development) using digital technology. Third, this study used a five-item scale to measure corporate operational performance in the realms of quality, cost, delivery, and flexibility, which have been widely used in the operations and supply chain management literature $[43,44]$. Appendix A presents the questionnaire used in this study.

\subsection{Sample}

This study collected data from South Korea and Vietnam. First, 248 companies responded to the survey from a sample of 850 Korean small- and medium-sized exporting B2B companies. We used 187 cases by excluding non-suppliers and missing data. Second, we conducted the same survey on Vietnamese exporting firms that supplied their products to large global firms. A total of 219 responses were collected out of 682 Vietnamese exporting firms in the area of Ho Chi Minh City. For the same reason, this study used 193 data for the analysis. Table 1 presents a summary of the responses.

Table 1. Summary of the survey.

\begin{tabular}{ccccccc}
\hline Country & $\begin{array}{c}\text { Total Number of } \\
\text { Questionnaires Sent }\end{array}$ & Responses & $\begin{array}{c}\text { Usable } \\
\text { Responses }\end{array}$ & $\begin{array}{c}\text { Response Rate } \\
\text { (\%) }\end{array}$ & $\begin{array}{c}\text { Average No. of } \\
\text { Employee }\end{array}$ & $\begin{array}{c}\text { Average of } \\
\text { Sales Revenue } \\
\text { (Million USD) }\end{array}$ \\
\hline $\begin{array}{c}\text { South Korea } \\
\text { Vietnam }\end{array}$ & 850 & 248 & 187 & 22.2 & 83 & 17.3 \\
\hline
\end{tabular}

\subsection{Measurement Test}

Table 2 provides the results of the measurement tests. We used confirmatory factor analysis (CFA) for convergent validity. Cronbach's alpha, average variance extract (AVE), and composite reliability support the constructs' reliability and internal consistency [45]. 
We assessed the discriminant validity by examining whether the square root of the AVE of each variable is higher than the correlation coefficients between the two variables [46].

Table 2. The results of constructs' reliability and validity.

\begin{tabular}{|c|c|c|c|c|c|}
\hline Construct & Items & Loading (CFA) & Cronbach's Alpha & Composite Reliability & AVE \\
\hline \multirow{5}{*}{$\begin{array}{c}\text { The environmental dimension } \\
\text { of sustainable SCM }\end{array}$} & ESCM01 & 0.66 & \multirow{5}{*}{0.87} & \multirow{5}{*}{0.88} & \multirow{5}{*}{0.60} \\
\hline & ESCM02 & 0.80 & & & \\
\hline & ESCM03 & 0.74 & & & \\
\hline & ESCM04 & 0.78 & & & \\
\hline & ESCM05 & 0.80 & & & \\
\hline \multirow{5}{*}{$\begin{array}{l}\text { The social dimension of } \\
\text { sustainable SCM }\end{array}$} & SSCM01 & 0.87 & \multirow{5}{*}{0.94} & \multirow{5}{*}{0.94} & \multirow{5}{*}{0.75} \\
\hline & SSCM02 & 0.89 & & & \\
\hline & SSCM03 & 0.92 & & & \\
\hline & SSCM04 & 0.80 & & & \\
\hline & SSCM05 & 0.84 & & & \\
\hline \multirow{5}{*}{$\begin{array}{l}\text { Digital-based supply chain } \\
\text { integration }\end{array}$} & DSCI01 & 0.71 & \multirow{5}{*}{0.85} & & \multirow{5}{*}{0.60} \\
\hline & DSCI02 & 0.75 & & \multirow{4}{*}{0.82} & \\
\hline & DSCI03 & 0.67 & & & \\
\hline & DSCI04 & 0.75 & & & \\
\hline & DSCI05 & 0.82 & & & \\
\hline \multirow{4}{*}{ Operational performance } & PERF01 & 0.84 & \multirow{4}{*}{0.92} & \multirow{4}{*}{0.87} & \multirow{4}{*}{0.64} \\
\hline & PERF02 & 0.61 & & & \\
\hline & PERF03 & 0.82 & & & \\
\hline & PERF04 & 0.87 & & & \\
\hline
\end{tabular}

\section{Results and Discussion}

\subsection{Descriptive Analysis}

Table 3 presents descriptive statistics and results of the correlation analysis. This study used a $t$-test analysis to investigate the similarities and differences in sustainable SCM practices in Korean and Vietnamese contexts. Then, we employed structural equation modeling (SEM) to test hypotheses. LISREL 8.30 [47], based on a covariance matrix, was used for the analysis. We analyzed each model of the Korea and Vietnam cases separately. Table 4 indicates a good fit for the model $[48,49]$.

Table 3. Correlation matrix.

\begin{tabular}{lcccccc}
\hline \multicolumn{1}{c}{ Variable } & Mean & S.D. & $\mathbf{1}$ & $\mathbf{2}$ & $\mathbf{3}$ & $\mathbf{4}$ \\
\hline 1. Sustainable SCM (Environment) & 4.83 & 1.36 & $(0.77)$ & & & \\
2. Sustainable SCM (Social) & 4.30 & 1.60 & $0.63^{* * *}$ & $(0.91)$ & \\
3. Digital-based supply chain integration & 4.25 & 1.23 & $0.45^{* * *}$ & $0.38^{* * *}$ & $(0.76)$ & \\
4. Operational competitiveness & 4.85 & 1.46 & $0.44^{* * *}$ & $0.59^{* * *}$ & $0.30^{* * *}$ & $(0.80)$ \\
\hline
\end{tabular}

Note: Figures along the diagonal in brackets indicate the square root of the AVE. ${ }^{* *}, p<0.01$.

Table 4. Fit of the measurement and structural models.

\begin{tabular}{ccccccc}
\hline Fit Indices & $\chi^{2} /$ d.f. & RMSEA & GFI & IFI & NNFI & CFI \\
\hline Desirable or marginal range & $\leq 3.0$ & $\leq 0.08$ & $\geq 0.80$ & $\geq 0.90$ & $\geq 0.90$ & $\geq 0.90$ \\
Measurement model & 1.88 & 0.85 & 0.84 & 0.92 & 0.93 & 0.93 \\
Structural model & & & & & & \\
The Korean case & 1.64 & 0.09 & 0.85 & 0.92 & 0.92 & 0.93 \\
The Vietnamese case & 2.55 & 0.10 & 0.80 & 0.91 & 0.88 & 0.90 \\
\hline
\end{tabular}

\subsection{Hypotheses Test and Discussion}

This study compared the sustainable SCM practices for the two country settings on each of the two dimensions: environmental and social aspects. Table 5 provides a 
summary of the analysis. First, the results show that some sustainable SCM practices are higher for Vietnamese supply firms than Korean ones at a significant level: the extent of buyers' environmental performance evaluation of the supplier, environmental support, and collaborative work on greener product development. It is noteworthy that non-significant items indicate that similarities exist between the two countries' cases in the practices of buyers' environmental audits and ISO certification requirements. Overall, the results partially supported Hypothesis 1.

Table 5. Comparison of sustainable SCM practices.

\begin{tabular}{|c|c|c|c|}
\hline Item & South Korea $(N=187)$ & Vietnam $(N=193)$ & $t$-Value \\
\hline \multicolumn{4}{|c|}{ The environmental dimension of sustainable SCM } \\
\hline ESSCM01. Environmental performance evaluation & 5.12 & 5.49 & $1.77 *$ \\
\hline ESSCM02. Environmental audit & 4.64 & 4.73 & 0.49 \\
\hline ESSCM03. Certification requirement & 5.02 & 5.23 & 1.14 \\
\hline ESSCM04. Environmental support (knowledge transfer and training) & 4.31 & 4.75 & $2.68^{* * *}$ \\
\hline ESSCM05. Green product co-development & 4.35 & 4.66 & $1.74 *$ \\
\hline \multicolumn{4}{|c|}{ The social dimension of sustainable SCM } \\
\hline SSSCM01. Social performance evaluation & 4.57 & 4.87 & 1.46 \\
\hline SSSCM02. Social audit & 4.14 & 4.11 & 0.17 \\
\hline SSSCM03. A code of conducts compliance & 4.37 & 4.46 & 0.46 \\
\hline SSSCM04. Social support (information sharing and training) & 4.16 & 4.06 & -0.53 \\
\hline SSSCM05. Precautionary response & 4.25 & 4.66 & 1.03 \\
\hline
\end{tabular}

Vietnamese suppliers recognized the rigorous environmental demands of their buyers than Korean suppliers when they export products. That implies that global buyers outside Vietnam are placing pressure on their supply chain partners in Vietnam to become more environmentally sound. To mitigate supply chain risks related to environmental issues, global brands often seek suppliers showing higher environmental performance and a conventional competitive advantage of low costs. One item with the most substantial difference across countries is buyers' environmental support. Such support includes environmental skills, training, and education. In addition, Vietnamese suppliers show a higher level in collaborative work with their buyers for greener product development than Korean suppliers. These differences indicate that Vietnamese firms' green capabilities are relatively lower than those of Korean firms. Because Vietnamese exporting companies are not equipped to address such environmental issues, global buyers are likely to provide them with higher levels of support while imposing intense pressure. This study examined the effects of sustainable SCM's environmental and social dimensions on the supplier's sustainability performance and operational competitiveness in the two different country settings. Overall, the results in Figure 1 provide support for Hypotheses 2 and 3.

The Korean case

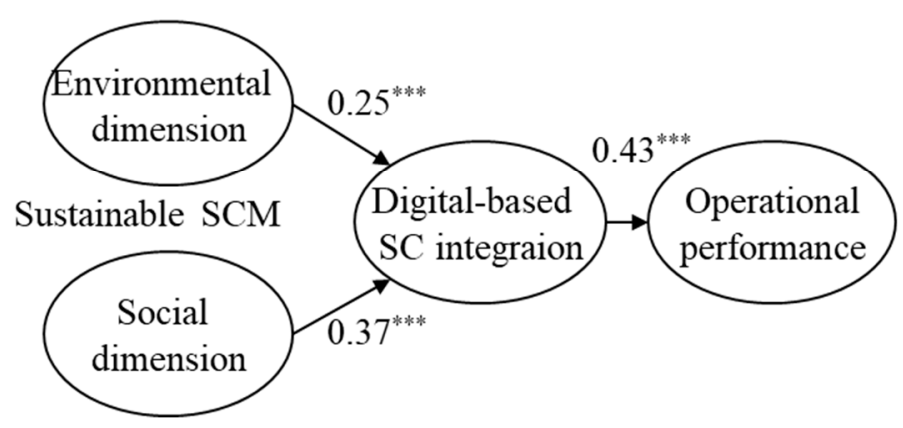

The Vietnamese case

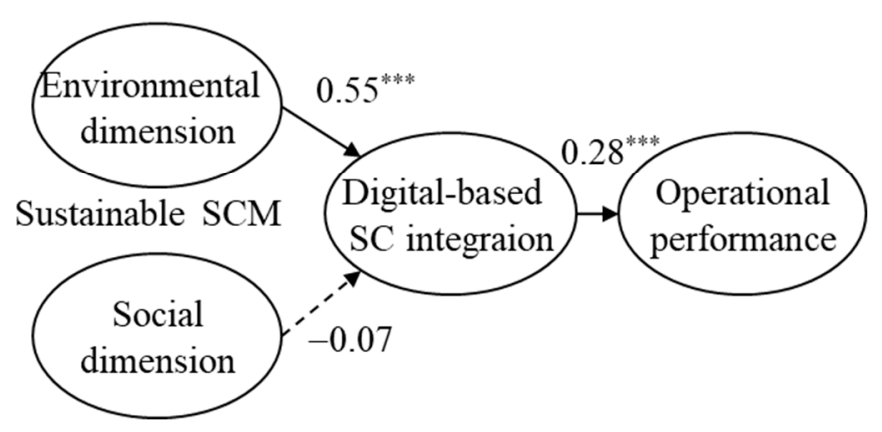

Figure 1. The results of structural equation modeling. ${ }^{* * *} p<0.01$. 
First, green SCM (the environmental dimension) had a significant and positive relationship with sustainability performance in Korea and Vietnam. That indicates that global buying companies' effective monitoring and support contribute to Korean and Vietnamese suppliers' sustainability performance. This result is very in line with previous studies on the environmental strategies of Asian companies [33]. For instance, Cho and Voss [50] found that South Korean quickly adopted and implemented environmental strategy in the mid-2000s when they confronted an unexpected and stringent environmental demand of their global buyer for hazardous substance-free certification. As for the social dimension, its positive effect on sustainability performance was founded only in the Korean context. This result might imply that the environmental aspect is more critical for sustainability performance than the social dimension in the Vietnamese supply chain. Alternatively, if green SCM's effect is overwhelming other influential factors, the impact of the social SCM on sustainability performance may not be significant. We found that sustainable SCM enhanced Korean and Vietnamese suppliers' capability and performance for addressing environmental and social issues.

Second, the results provided evidence of a direct relationship between sustainability performance and corporate operational competitiveness. This result supports some previous studies that acknowledge the possibility of the triple bottom line in the supply chain $[8,25,51]$. Also, it is noteworthy that sustainable SCM increases the supplier's operational competitiveness through sustainability performance. These results support our second hypothesis.

Third, the results support Hypothesis 3, the differences in the effects of sustainable SCM on sustainability performance and corporate competitiveness between Korea's and Vietnam's cases. The environmental dimension has a more significant relationship with sustainability $(\beta=0.78$ and $t=5.78)$ than the social aspect $(\beta=-0.13$ and $t=1.19)$ in the Vietnamese situation. In contrast, the social dimension's effect on sustainability performance $(\beta=0.40$ and $t=0.78)$ is greater than the environmental dimension $(\beta=0.29$ and $t=0.40)$ in the Korean case. The results also verify that the relationship between the supplier's sustainability performance and operational competitiveness is less in the Vietnamese case $(\beta=0.54$ and $t=6.33)$ than in the Korean case $(\beta=0.70$ and $t=6.96)$. As expected, the contextual difference between South Korea and Vietnam may cause such relationships to varying. For instance, when exporting products, environmental concerns are significant in the Vietnamese supply chain. Besides, economic factors such as a large workforce with relatively low wages and labor productivity may be considered one of the main competitive advantages of Vietnamese suppliers. This result is very much in line with some of the statistics that illustrate labor-intensive manufactured goods, such as textile and footwear, were the most fast-growing export segments [52].

\section{Conclusions}

\subsection{Theoretical and Practical Implications}

By combining sustainability, inter-organizational integration, and digitization in supply chains, this study lays the groundwork for future theoretical work in sustainable and digital supply chain dynamics. First, this study contributes to the existing literature on supply chain management by exploring the intersection of sustainability and digitization. A few studies have recently addressed this topic; however, they tend to focus on Industry 4.0 technologies, such as blockchain and big data, as antecedents of sustainable SCM [53]. This study widens this argument by providing evidence of reverse causality, indicating the positive effect of sustainable SCM on digital-based supply chain integration. Sustainability and digital-based integration along a supply chain can be parallel because they are essentially reciprocal programs. This result implies that social capital theory [31,54], explaining competitive advantages as the results of valuable assets that stem from access to resources made available social relationships in firms' social network, can be extended to the supply chain digitization context. Second, this study proposes a better explanation of how sustainable SCM differently influences the implementation of digital-based supply 
chain integration with global buyers and operational performance in the different country settings. South Korea represents a mature industry environment, whereas Vietnam is an emerging economy. The results highlight that the global supply chain has contributed to increasing sustainability practices in Asian countries. Sustainability issues have emerged in the business circles in South Korea and Vietnam; however, priorities vary depending on the two countries' settings. The extent of environmental requirements and support from global buyers are more influential in the Vietnamese supply chain than in the Korean supply chain, implying that the environmental issue is a more pressing matter in the Vietnam case. This result aligns with the resource-based view (RBV), stakeholder theory, and institutional theory to depict changes in sustainable SCM in different country contexts. RBV and stakeholder theory [55], arguing that a firm's behavior and performance might be determined by the specific resources of the firm and pressures from its stakeholders, provide a theoretical ground to explain why and how sustainable SCM practices vary in different contexts. Institutional theory, focusing on the intersection between individual firms and societal players, can describe how companies build the consensus around emerging sustainability issues and sustainable SCM practices proliferate along global value chains [56].

This study provides several managerial and policy implications for enhancing supply chain performance by utilizing digital technologies along a global supply chain. First, sustainable SCM can enable Asian suppliers to adopt and implement sustainability practices. Supplying companies' sustainability performance can be improved by their global buyers' monitoring- and support-based supply chain practices. Collectively, supply chain partners (i.e., buyers and suppliers) should acknowledge that they can benefit from partnership and collaboration through sustainable SCM $[10,16]$. Second, this study provides evidence that sustainable SCM, which aims to improve sustainability performance through monitoring and support practices of buying firms to supplying firms, helps supply chain partners adopt digital technologies for information and operations integration along a supply chain. Sustainable SCM is a reciprocal program based on mutual recognition, trust, and longterm partnership, coordinating misaligned objectives and reducing concerns regarding confidential information sharing and misaligned goals. Supply chain integration using digital technologies has become a prominent trend nowadays. However, many companies encounter several obstacles hindering the adoption and implementation of supply chain digitization. In this situation, sustainable SCM plays a critical role in facilitating digital-based supply chain integration by lowering those barriers, improving operational performance such as quality, cost, delivery, and lead time. Third, we present that sustainable SCM and digital-based supply chain integration can be parallel and improve suppliers operational performance in Korea and Vietnam. Supplying firms in these regions may increasingly receive stringent requirements regarding environmental and social issues from their global buyers. Their buyers in the global value chain may increasingly demand to adopt digital technologies to share order, inventory, production, and product information. In this case, they need to take such sustainability and digital requirements as opportunities to improve their operational competitiveness. Fourth, significant progress has been made in sustainability practices and digitization in Asian countries; however, there might be differences in priorities of these issues. Managers of Korean and Vietnamese supplying firms continuously should be keenly conscious of various global, environmental, social, and digital technology concerns from their international buying firms. They should respond to them in a timely and adequate manner.

\subsection{Limitations and Future Research Directions}

This study suggests some directions for future research. First, this study investigated differences in sustainable SCM practices of the two country settings. Future studies need to investigate the effects of institutional factors, such as social and environmental pressure, regulations, policies, and industrial and digital technological infrastructure, which are likely to influence sustainability practices. Second, this study analyzed sustainable SCM and digital-based supply chain integration from a supplier perspective by collecting the 
supplier-side data. Extending this work to a dyadic perspective of sustainable SCM, collecting data from both sides of the buying firms and their suppliers is needed for a clear picture of sustainability practices, supply chain digitization, and competitiveness. Third, this study employed perceptual measures using a survey method. Future studies can consider objective financial performance measures for performance, such as sales and market share, the return of investment (ROI), and profits.

Funding: This research received no external funding.

Institutional Review Board Statement: Not applicable.

Informed Consent Statement: Not applicable.

Data Availability Statement: The data presented in this study are available on request from the corresponding author.

Conflicts of Interest: The author declares no conflict of interest.

Appendix A. Questionnaires

\begin{tabular}{|c|c|c|}
\hline Variable & Item Code & Item \\
\hline \multirow{7}{*}{$\begin{array}{c}\text { The environmental dimension } \\
\text { of sustainable SCM }\end{array}$} & ESSCM01 & $\begin{array}{c}\text { To what extent do you agree or disagree with each of the following } \\
\text { statements }(1=\text { not at all, } 4=\text { moderately, and } 7=\text { very much)? } \\
\text { For the last two years, our major customer has ... } \\
\text { evaluated our environmental performance in a formal supplier } \\
\text { selection process. }\end{array}$ \\
\hline & ESSCM02 & visited our operational site to do environmental audits. \\
\hline & ESSCM03 & demanded environmental management certification. \\
\hline & ESSCM04 & $\begin{array}{l}\text { provided us with environmental information and know-how, and } \\
\text { technical, managerial and financial assistance. }\end{array}$ \\
\hline & ESSCM05 & helped our firm develop environmental-friendly products. \\
\hline & SSSCM01 & evaluated our social performance in a formal supplier selection process. \\
\hline & SSSCM02 & visited our operational site to do social audits. \\
\hline \multirow{3}{*}{$\begin{array}{l}\text { The social dimension of } \\
\text { sustainable SCM }\end{array}$} & SSSCM03 & $\begin{array}{l}\text { demanded us to assure to comply with global social standards (e.g., the } \\
\text { UN Global Compact) }\end{array}$ \\
\hline & SSSCM04 & $\begin{array}{l}\text { provided us with environmental information and know-how, and } \\
\text { technical, managerial and financial assistance. }\end{array}$ \\
\hline & SSSCM05 & helped our firm cope with possible social issues in a precautionary way. \\
\hline \multirow{6}{*}{$\begin{array}{l}\text { Digital-based supply chain } \\
\text { integration }\end{array}$} & & $\begin{array}{c}\text { To what extent do you agree or disagree with each of the following } \\
\text { statements }(1=\text { not at all, } 4=\text { moderately, and } 7=\text { very much)? } \\
\text { For the last two years, our firm and our major customer have } \ldots \\
\text { [digital technologies include EDI, ERP, big data analytics, the Internet } \\
\text { of things, and social media] }\end{array}$ \\
\hline & DSCI01 & shared order information using digital technologies \\
\hline & DSCI02 & shared inventory information using digital technologies \\
\hline & DSCI03 & shared production planning and schedule using digital technologies \\
\hline & DSCI04 & $\begin{array}{l}\text { made coordinated and joint decisions regarding stock replenishment } \\
\text { using digital technologies }\end{array}$ \\
\hline & DSCI05 & collaborated for new product development using digital technologies \\
\hline \multirow{5}{*}{ Operational performance } & & $\begin{array}{l}\text { How does your firm compare with primary competitors? }(1=\text { far } \\
\text { worse, } 4=\text { the same as, and } 7=\text { far better })\end{array}$ \\
\hline & PERF01 & Quality \\
\hline & PERF02 & Costs \\
\hline & PERF03 & Flexibility \\
\hline & PERF04 & On-time delivery \\
\hline
\end{tabular}

\section{References}

1. Jajja, M.S.S.; Chatha, K.A.; Farooq, S. Impact of supply chain risk on agility performance: Mediating role of supply chain integration. Int. J. Prod. Econ. 2018, 205, 118-138. [CrossRef] 
2. Pellegrino, R.; Costantino, N.; Tauro, D. Supply Chain Finance: A supply chain-oriented perspective to mitigate commodity risk and pricing volatility. J. Purch. Supply Manag. 2019, 25, 118-133. [CrossRef]

3. Pettit, T.J.; Croxton, K.; Fiksel, J. Ensuring Supply Chain Resilience: Development and Implementation of an Assessment Tool. J. Bus. Logist. 2013, 34, 46-76. [CrossRef]

4. Villena, V.H.; Gioia, D.A. A more sustainable supply chain. Harvard Business Review. 2020. Available online: https://hbr.org/20 20/03/a-more-sustainable-supply-chain (accessed on 22 June 2021).

5. Lee, S.H.; Moi, M.J.; Mellahi, K. Apple and Its Suppliers: Corporate Social Responsibility; Ivey Publishing, Richard Ivey School of Business, The Western University: London, ON, Canada, 2016.

6. Quang, H.T.; Hara, Y. Risks and performance in supply chain: The push effect. Int. J. Prod. Res. 2017, 56, 1369-1388. [CrossRef]

7. Pagell, M.; Wu, Z.; Wasserman, M.E. Thinking differently about purchasing portfolios: An assessment of sustainable sourcing. J. Supply Chain Manag. 2010, 46, 57-73. [CrossRef]

8. Lee, S.-Y. Responsible supply chain management in the Asian context: The effects on relationship commitment and supplier performance. Asia Pac. Bus. Rev. 2015, 22, 325-342. [CrossRef]

9. Rao, P.; Holt, D. Do green supply chains lead to competitiveness and economic performance? Int. J. Oper. Prod. Manag. 2005, 25, 898-916. [CrossRef]

10. Akhtar, P. Warsaw School of Economics Drivers of Green Supply Chain Initiatives and their Impact on Economic Performance of Firms: Evidence from Pakistan's Manufacturing Sector. J. Compet. 2019, 11, 5-18. [CrossRef]

11. Rao, P.H. Green supply chain management. A study based on SMEs in India. J. Supply Chain Manag. Syst. 2019, 8, 15-24.

12. Agrawal, P.; Narain, R.; Ullah, I. Analysis of barriers in implementation of digital transformation of supply chain using interpretive structural modelling approach. J. Model. Manag. 2019, 15, 297-317. [CrossRef]

13. Büyüközkan, G.; Göçer, F. Digital Supply Chain: Literature review and a proposed framework for future research. Comput. Ind. 2018, 97, 157-177. [CrossRef]

14. Lii, P.; Kuo, F.-I. Innovation-oriented supply chain integration for combined competitiveness and firm performance. Int. J. Prod. Econ. 2016, 174, 142-155. [CrossRef]

15. Dougados, M.; Felgendreher, B. The Current and Future State of Digital Supply Chain Transformation. 2016. Available online: https://www.supplychainquarterly.com/ext/resources/files/pdfs/whitepapers/gtexus_digital_transformation.pdf? 1589233644 (accessed on 30 April 2021).

16. Ageron, B.; Gunasekaran, A.; Spalanzani, A. Sustainable supply management: An empirical study. Int. J. Prod. Econ. 2012, 140, 168-182. [CrossRef]

17. Seuring, S.; Müller, M. From a literature review to a conceptual framework for sustainable supply chain management. J. Clean. Prod. 2008, 16, 1699-1710. [CrossRef]

18. Oelze, N. Sustainable Supply Chain Management Implementation-Enablers and Barriers in the Textile Industry. Sustainability 2017, 9, 1435. [CrossRef]

19. Queiroz, M.M.; Pereira, S.C.F.; Telles, R.; Machado, M.C. Industry 4.0 and digital supply chain capabilities: A framework for understanding digitalisation challenges and opportunities. Benchmarking Int. J. 2019, 28. [CrossRef]

20. Lee, S.-Y.; Klassen, R. Drivers and Enablers That Foster Environmental Management Capabilities in Small- and Medium-Sized Suppliers in Supply Chains. Prod. Oper. Manag. 2008, 17, 573-586. [CrossRef]

21. Chapple, W.; Moon, J. Corporate Social Responsibility (CSR) in Asia. Bus. Soc. 2005, 44, 415-441. [CrossRef]

22. Carter, C.R.; Jennings, M.M. Social responsibility and supply chain relationships. Transp. Res. Part E Logist. Transp. Rev. 2002, 38, 37-52. [CrossRef]

23. Klassen, R.D.; Vereecke, A. Social issues in supply chains: Capabilities link responsibility, risk (opportunity), and performance. Int. J. Prod. Econ. 2012, 140, 103-115. [CrossRef]

24. Vachon, S.; Klassen, R. Extending green practices across the supply chain. Int. J. Oper. Prod. Manag. 2006, 26, 795-821. [CrossRef]

25. Zhu, Q.; Sarkis, J. Relationships between operational practices and performance among early adopters of green supply chain management practices in Chinese manufacturing enterprises. J. Oper. Manag. 2004, 22, 265-289. [CrossRef]

26. Bai, C.; Sarkis, J. Integrating sustainability into supplier selection with grey system and rough set methodologies. Int. J. Prod. Econ. 2010, 124, 252-264. [CrossRef]

27. Schell, O. How Walmart Is Chaining China. The Atlantic. 2011. Available online: http://www.theatlantic.com/magazine/ archive/2011/12/how-walmart-is-changing-china/308709/ (accessed on 22 June 2021).

28. Xu, Q.; Hu, Q.; Chin, T.; Chen, C.; Shi, Y. How Supply Chain Integration Affects Innovation in a Digital Age: Moderating Effects of Sustainable Policy. Sustainability 2019, 11, 5460. [CrossRef]

29. Vanpoucke, E.; Vereecke, A.A.; Muylle, S.S. Leveraging the impact of supply chain integration through information technology. Int. J. Oper. Prod. Manag. 2017, 37, 510-530. [CrossRef]

30. Kayikci, Y. Sustainability impact of digitization in logistics. Procedia Manuf. 2018, 21, 782-789. [CrossRef]

31. Nahapiet, J.; Ghoshal, S. Social capital, intellectual, capital, and the organizational advantage. Acad. Manag. Rev. 1998, 23, $242-266$. [CrossRef]

32. Gimenez, C.; van der Vaart, T.; Pieter van Donk, D. Supply chain integration and performance: The moderating effect of supply complexity. Int. J. Oper. Prod. Manag. 2012, 32, 583-610. [CrossRef] 
33. Zhu, Q.; Crotty, J.; Sarkis, J. A Cross-Country Empirical Comparison of Environmental Supply Chain Management Practices in the Automotive Industry. Asian Bus. Manag. 2008, 7, 467-488. [CrossRef]

34. Lee, S.-Y.; Klassen, R.; Furlan, A.; Vinelli, A. The green bullwhip effect: Transferring environmental requirements along a supply chain. Int. J. Prod. Econ. 2014, 156, 39-51. [CrossRef]

35. Lee, S.-Y. The effects of green supply chain management on the supplier's performance through social capital accumulation Supply Chain Manag. Int. J. 2015, 20, 42-55. [CrossRef]

36. Chiang, C.-T.; Kou, T.-C.; Koo, T.-L. A Systematic Literature Review of the IT-Based Supply Chain Management System: Towards a Sustainable Supply Chain Management Model. Sustainability 2021, 13, 2547. [CrossRef]

37. Prajogo, D.; Olhager, J. Supply chain integration and performance: The effects of long-term relationships, information technology and sharing, and logistics integration. Int. J. Prod. Econ. 2012, 135, 514-522. [CrossRef]

38. Leuschner, R.; Rogers, D.S.; Charvet, F.F. A Meta-Analysis of Supply Chain Integration and Firm Performance. J. Supply Chain Manag. 2013, 49, 34-57. [CrossRef]

39. Li, G.; Yang, H.; Sun, L.; Sohal, A.S. The impact of IT implementation on supply chain integration and performance. Int. J. Prod. Econ. 2009, 120, 125-138. [CrossRef]

40. Saygin, D.; Patel, M.K.; Worrell, E.; Tam, C.; Gielen, D.J. Potential of best practice technology to improve energy efficiency in the global chemical and petrochemical sector. Energy 2011, 36, 5779-5790. [CrossRef]

41. Green, K.W., Jr.; Zelbst, P.J.; Meacham, J.; Bhadauria, V.S. Green supply chain management practices: Impact on performance. Supply Chain Manag. Int. J. 2012, 17, 290-305. [CrossRef]

42. Carter, C.R. Purchasing and Social Responsibility: A Replication and Extension. J. Supply Chain Manag. 2004, 40, 4-16. [CrossRef]

43. Krause, D.R.; Handfield, R.B.; Tyler, B.B. The relationships between supplier development, commitment, social capital accumulation and performance improvement. J. Oper. Manag. 2006, 25, 528-545. [CrossRef]

44. Ward, P.T.; McCreery, J.K.; Ritzman, L.P.; Sharma, D. Competitive Priorities in Operations Management. Decis. Sci. 1998, 29, 1035-1046. [CrossRef]

45. Hair, J.F.; Sarstedt, M.; Ringle, C.M.; Mena, J.A. An assessment of the use of partial least squares structural equation modeling in marketing research. J. Acad. Mark. Sci. 2012, 40, 414-433. [CrossRef]

46. Fornell, C.; Larcker, D.F. Evaluating Structural Equation Models with Unobservable Variables and Measurement Error. J. Mark. Res. 1981, 18, 39-50. [CrossRef]

47. Joreskog, K.G.; Sorbom, D. LISREL 8: User's Reference Guide; SSI Inc.: Chicago, IL, USA, 1996.

48. Hu, L.T.; Bentler, P.M. Cutoff criteria for fit indexes in covariance structure analysis: Conventional criteria versus new alternatives. Struct. Equ. Model. Multidiscip. J. 1999, 6, 1-55. [CrossRef]

49. Browne, M.W.; Cudek, R. Alternative ways of assessing model fit. In Testing Structural Equation Models; Bollen, K.A., Long, J.S., Eds.; Sage: Newbury, CA, USA, 1993; pp. 136-162.

50. Cho, E.; Voss, H. Determinants of international environmental strategies of Korean firms: An explorative case-study approach. Asian Bus. Manag. 2011, 10, 357-380. [CrossRef]

51. Geng, R.; Mansouri, S.A.; Aktas, E. The relationship between green supply chain management and performance: A meta-analysis of empirical evidences in Asian emerging economies. Int. J. Prod. Econ. 2017, 183, 245-258. [CrossRef]

52. Breu, M.; Dobbs, R.; Remes, J.; Skilling, D.; Kim, J. Sustaining Vietnam's Growth: The Productivity Challenge. McKinsey Global Institute Report. 2012. Available online: https://www.mckinsey.com/ \{\}/media/McKinsey/Featured\%20Insights/Asia\%20 Pacific/Sustaining\%20growth\%20in\%20Vietnam/MGI_Sustaining_growth_in_Vietnam_Executive_Summary.pdf (accessed on 17 July 2015).

53. Saberi, S.; Kouhizadeh, M.; Sarkis, J.; Shen, L. Blockchain technology and its relationships to sustainable supply chain management. Int. J. Prod. Res. 2019, 57, 2117-2135. [CrossRef]

54. Inkpen, A.C.; Tsang, E.W.K. Social Capital, Networks, and Knowledge Transfer. Acad. Manag. Rev. 2005, 30, 146-165. [CrossRef]

55. Barney, J. Firm Resources and Sustained Competitive Advantage. J. Manag. 1991, 17, 99-120. [CrossRef]

56. Hoffman, A.J. From Heresy to Dogma: An Institutional History of Corporate Environmentalism; The New Lexington Press: San Francisco, CA, USA, 1997. 